sick patients. On the other hand, the clinician has little time to undertake applied research. Considerable improvement in medicine would occur if money could be provided to finance multidisciplinary teams on well-planned projects in which industry would collaborate by developing the necessary technology.

But at the moment the need to treat more patients than ever before clashes with increasingly rigid budgetary con- straints. As in so many areas, but particularly in research, a world of priorities means that the capacity to find technological solutions might exist but the economic encouragement often does not.
I have just returned from attending the Fourth International Conference on the Unity of the Sciences, held at the Waldorf-Astoria Hotel in New York from November 27-30. The subject of the conference was "The Centrality of Science and Absolute Values", and it was attended by some 350 of what the programme describes as "the world's most eminent scholars and scientists" from 60 different countries. Readers of Nature will remember the editorial, "Bringing men to the Moon", published on October 25 1974, just before the Third Conference was held in London last November. The editorial questioned the status of the International Cultural Foundation, which was sponsoring (and financing) the conference.

The Foundation was started by the Reverend Sun Myung Moon, who is also the founder of the Unification Church. This church has been severely criticised, mainly for its strong anticommunist views, and for what some consider its undue influence on young converts. The Nature article suggested that the participants in the conference might find that they were being used to give respectability to an organisation of which they did not entirely approve. Although the ICF exists as "a non-profit organisation dedicated to promoting academic, scientific, religious and cultural exchange among the countries of the world", critics have suggested that its aims may be less disinterested and more political.

The Fourth Conference included a few representatives from communistgoverned states. Invitations had been sent to several people in Soviet Russia, but these were not accepted-an experience not unknown to organisers of the most orthodox scientific gathering. But scientists came from Hungary, Poland and Yugoslavia. In 1974 India was not represented, but this time several Indians attended, as did Egyptians, Lebanese, Israelis, and many others from "third world" countries. As before, we had a galaxy of Nobel Laureates, in physics, chemistry, physiology and other subjects. Several theologians, including Jesuits and other Roman Catholics, as well as members of other sects and different religions, were among the participants. The social sciences were well represented.

Last year the advance announcements about the Third Conference listed eminent names of supporters and participants, some of whom later dissociated themselves with the organisation. The opinion was stated (in Nature and elsewhere) that this might have been done to try to secure wider

\section{Attending a Moon conference}

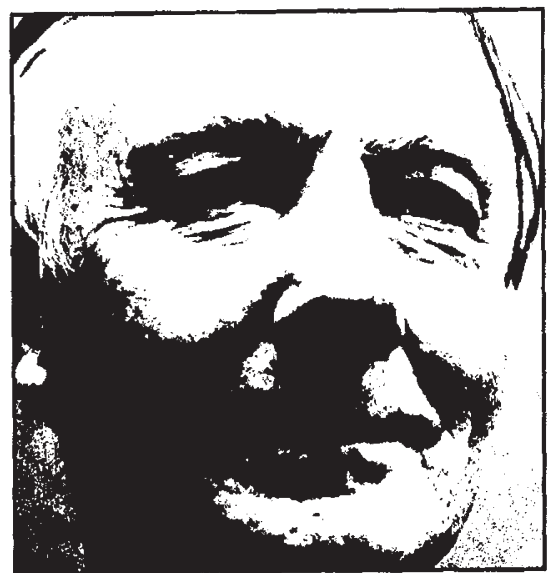

KENNETH MELLANBY

support. I believe that the use of any names without permission was due to misunderstanding -1 know one Briton who was approached who said he could not attend but " "would help if he could", and then objected when he was listed as a supporter. This year I do not think that anyone was named who was not genuinely willing to help.

Critics of the ICF have queried the selection of those invited, and of the programme of the conference. They have suggested that members may have allowed themselves to be put in a position where they could not freely state their views. Regarding the selection: the invitations came from the ICF, but names were chosen by entirely independent committees of advisers, American and international (I must confess to being one of their number). I do not know of any case in which a name was suggested and the individual was not invited It is true that the majority of members were middle-aged, and that few strident marxists were included but they certainly included a wide range of opinions and beliefs. Any gaps were caused by refusals, and by the fact that the advisers did not wish to include those, however well intentioned, who would wreck the event. In fact a few uncompromising critics did attend.

There was no censorship of views or opinions whatever. The 120 or so papers, which were previously circulated to the groups which discussed them, were read by the committee chairman, and sometimes authors were asked to shorten their text, but no matters of substance were excluded. As one who chaired a discussion group I can confirm that no one was muzzled. The conference certainly cannot be criticised as not allowing complete freedom of expression to all participants.

The $\$ 500,000$ question remains to be answered: was the conference worth while? I personally think that the answer is "yes". Many equally expensive international gatherings, even those dealing with important scientific topics, are clearly a waste of time and money. Litt'ie new is said or heard-_"Professor Blank read his paper" (the same one read so often before). Here we had a gathering of gocd men and women with good minds who seriously discussed the problems facing the world today, and the ways in which science could and s'lould be involved.

I know of no other gathering where this would have been possible. There was less nonsense talked than might have been expected-in my opening address I echoed a warning in last year's Nature, when I said that the present disenchantment of the public with science and scientists was "sometimes generated by scientists themselves-when they appear to speak as experts in fields where they possess no expertise".

We attempted to define the boundaries of the various branches of science, and the relations between the natural and social sciences. We discussed the problem of values, in regard to the family, to religion and to morality. Consideration was given to problems facing universities and research institutions, and to the ethics of the application of modern technology. The position of science in resolving world inequalities and in the creation of any fuure world order was also discussed. We did not solve all the world's outstanding problems, but perhaps we made some progress in the right direction. 